血清 creatine phosphokinase(CPK)，ミオグロビンが

異常高值を示した糖尿病性ケトアシドーシスの 1 例

\begin{tabular}{|c|c|c|c|c|}
\hline \multicolumn{5}{|c|}{ 岐阜市民病院内科 } \\
\hline 棚橋 & 忍॰ & 奥野 文隆 & 寺倉 & 俊勝 \\
\hline 过 & 孝 & 若原 & 山田 & 重樹 \\
\hline
\end{tabular}

\title{
A CASE OF DIABETIC KETOACIDOSIS WITH A MARKEDLY INCREASED LEVEL OF SERUM CREATINE PHOSPHOKINASE(CPK) AND MYOGLOBIN
}

Shinobu Tanabashi, MD, Fumitaka OKuno, MD, Toshikatsu Terakura, MD, Takashi TsujI, MD, Tatsuo WaKaHARA, MD and Shigeki YamadA, MD

Department of Internal Medicine, Gifu City Hospital, Gifu

概要 血清CPK，ミオグロビンが異常高值を示した糖㽷病性ケトアシドーシスの 1 例を報告す る。症例は23才の女性で，以前に糖尿病と診断されたことはなかつた。 入院時昏睡，ショック 状態であつた，血糖は $526 \mathrm{mg} / \mathrm{dl} ，$ 血中，尿中ヶトン体は陽性であつた。動脈血 $\mathrm{pH}$ は 7.16 ，重炭 酸イオンは $9.2 \mathrm{mEq} / l$ であた. 少量インスリン持続注入尞法, 輸液にて覚醒した。 入院時血清 CPK, LDHはそれぞれ124IU/l, 181Wro.Uと正常であつたが，血清ミオグロビンは2745ng $/ \mathrm{ml}$ と上昇していた。治療開始後 $\mathrm{CPK}, \mathrm{LDH}$ は上昇し，ミオグロビンはさらに上昇した。血清ミオ グロビンは入院後 2 日目で11690ng $/ \mathrm{mlk}, \mathrm{CPK}, \mathrm{LDH} 3$ 日目にそれぞれ29000IU/l, 1758 Wro. Uと最高に上昇した。血清ミオグロビン，CPK，LDHは約10日で正常に復した，CPKア インザイムではMMが95〜97\%，LDHアインザイムではLDH H $_{5}$ 最高 $58.5 \%$ を占めていた。 心 電図には心筋硬塞を示す所見はなかつた。 また臨床上筋炎，外傷も認めず，筋注も行なわなか つた，肝生検では肝細胞壊死を認めなかつた，以上の検索より，本症例にみられた高CPKおよ び高ミオグロビン血症は骨格筋由来のCPK，ミオグロビンが血中に遊出したために生じたと考 えた. その機序として糖尿病性ケトアシドーシス, 脱ホ, ショックなどにより，骨格筋のanoxia が生じ, 細胞膜透過性え進が若起された可能性が重要と思われた。

\section{はじめに}

暙尿病性ケトアシドーシスに高creatine phosphokinase (以下CPK) 血症を認めた場合，まず第 一に心筋硬塞の合併を考えなけれぱならないであ ろう。しかし症状和よび心電図上心筋硬塞を疑わ 世る所見がないにもかかわらず，高CPK血症を呈 する者がまれにみられる2立，著者らも既にこう

[昭和56年 6 月 8 日受稿]
した 1 症例を報告しているが，血清ミオグロビン の検索を扣こなつて抢らず，必ずしも十分な症例 報告であつたとはいえなからた可。また過去の報 告例においては, 血清CPKアイソザイム, lactate dehydrogenase (LDH) アイソザイム, 血清ミオ グロビン，心電図などの検索がなされていない。 今回経験した症例においては, 血清CPKのみなら ず，血清ミオグロビン， glutamic oxaloacetic transaminase (GOT), glutamic pyruvic trans- 
Table 1. Loboratory findings on admission.

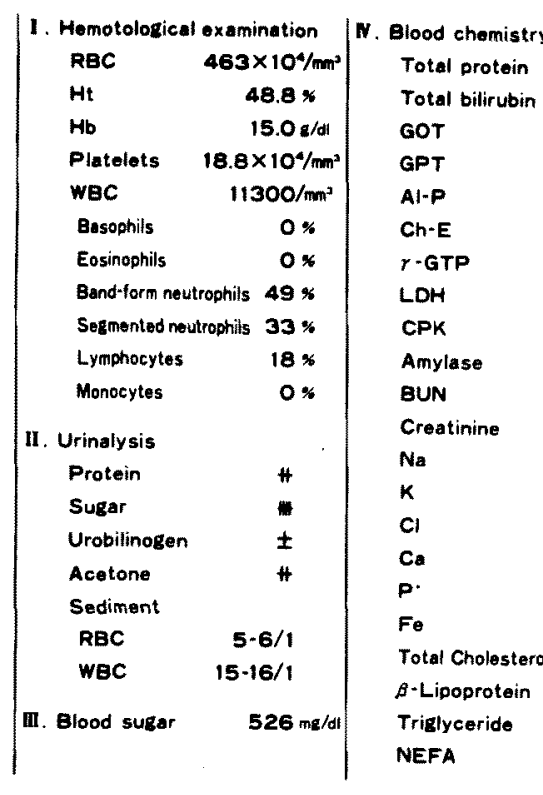

aminase (GPT)，LDHを経時的に測定した，血清 ミオグロビンの異常高值, CPKアインザイムにて MMが増加していた点より，血中に増加したCPK は骨格筋由来であることが判明した。これらの検 查成績をもとに，糖尿病性ヶトアシドーシスにみ られた高CPK血症の発生機序について考察を加 えた。

\section{症例}

患者 (84724-7)：23才, 女性, 事務員.

\section{主訴： 意識障害.}

家族歴：特記することはない。

既往歴：特記することはない。

現病歴：昭和54年11月下旬, 軽度の咽頭痛, 咳嗽，徽熱を認めたが，12月中旬には軽快した。 この当時体重は $47 \mathrm{~kg}$ であつた。昭和55年 1 月 15 日 頃上り口渴，多飲，多尿が出現した。2月 8 日頃 体重は43kgであつた，2月10日スキーに行つたの を契機に口渴，多飲，多尿が増強し，全身倦急感， 食欲低下す認め, 2 月 13 日体重は $38 \mathrm{~kg}$ となつた。 2 月17日夕食後悪心，呕吐を認め，18日朝よりつ じつまの合わないことを言い傾眠となつたため, 某病院へ入院した. 入院時体重は $35 \mathrm{~kg}$ であつた。 夕方上り呼びかけに対し覚醒しなくなつた。導尿

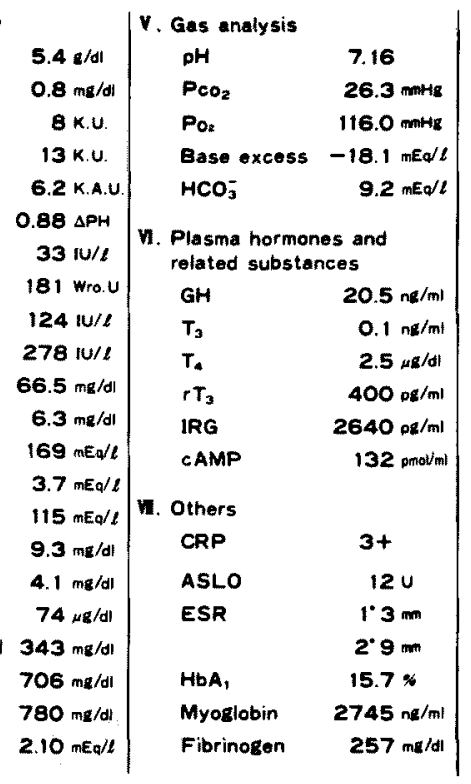

にて得られた尿にて尿糖，フセトン体ともに陽性 であつたので，糖疗病性笪睡の疑いで 2 月19日午 前 9 時 45 分当病院に入院した。

入院時現症：入院時呼びかけ，疼痛刺激に対 して反応はなく，深䒤睡の状態ですつた。皮膚は 乾燥し，四肢はつめたかつた。呼吸はクスマウル 呼吸で，毎分32回であつた，血王は測定不能であ つた。脈拍は140/分，整で，非常に微弱であつた。

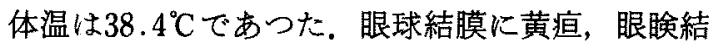
膜に責血を認めなかつた，瞳孔は正円，左右同大 で, 対光反射は正常であつた，舌は乾燥していた。 心，肺には打・聴款上異常を認めなかつた，腹部 は平坦で，肝，脾，腎を触知しなからた。下肢に 浮腫はなかつた。両側の膝蓋腱反射, アキレス腱 反射は消失していた。病的反射は認めなかつた。

入院時検査成績：入院時検查成績学Table 1 に示した，導尿で得られた尿にて尿蛋白(H)，尿 糖 (州)，アセトン体（H）であつた。血糖は526 $\mathrm{mg} / \mathrm{dl}$ で，血清アセトン体は(H)であつた。動脈 血のガス分析では， $\mathrm{pH} 7.16, \mathrm{Pco}_{2} 26.3 \mathrm{mmHg}$, base exess $-18.1 \mathrm{mEq} / l, \mathrm{HCO}_{3}^{-}$は9.2mEq/lで, metabolic acidosisを呈していた。血清電解質では ナトリウム,カリウム,クロールそれぞれ169,3.7, 


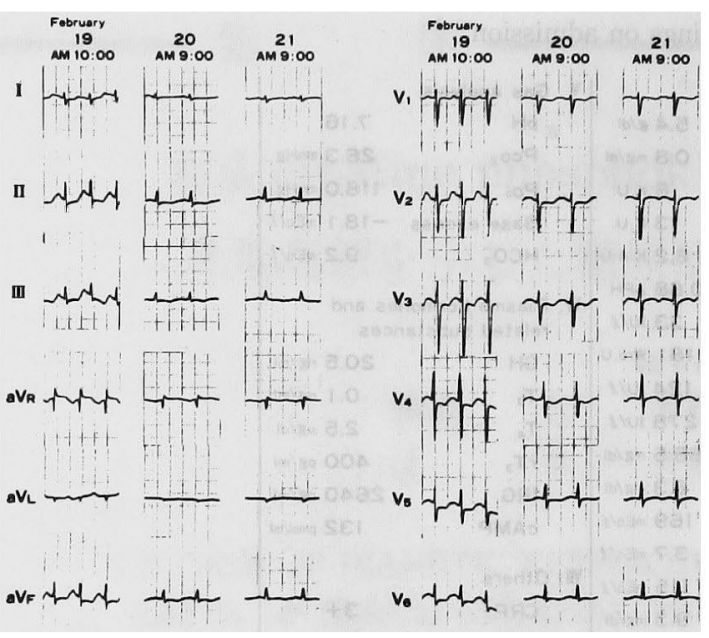

Fig 1. Electrocardiogram.

$115 \mathrm{mEq} /$ lであつた。血清尿素窒素, クレアチニ ン，尿酸はそれぞれ $66.5 ， 6.3,22.5 \mathrm{mg} / \mathrm{dl}$ ととも に高値であつた. 脂質は総コレステロール $343 \mathrm{mg} /$ $\mathrm{dl}, \beta$-リポタンパク $706 \mathrm{mg} / \mathrm{dl}$, 中性脂肪 $780 \mathrm{mg} /$ $\mathrm{dl}$, 遊離脂肪酸 $2.10 \mathrm{mEq} / l$ といずれも著増してい た．血清GOT, GPT, LDH, CPKはいずれも正常 範囲であつたが，血清ミオグロビンは入院時 2745 $\mathrm{ng} / \mathrm{ml}$ と高値であつた，血浆グルカゴン (IRG), 成長ホルモン (GH), adenosine $3^{\prime} 5^{\prime}$-monophosphate (cAMP) はそれぞれ $2640 \mathrm{pg} / \mathrm{ml}, 20.5 \mathrm{ng} /$ $\mathrm{ml}, 132 \mathrm{pmol} / \mathrm{ml}$ と著明な高値を示した。心電図 （Fig 1）は洞性頻脈（150/分）と， I, II, III, $a V_{F}, V_{3 \sim 6}$ のST低下（I 型）を認めた。胸部レン トゲン写真に異常所見を認めなかつた。

入院後経過： 昏睡に陥る以前に著明な口渴, 多飲, 多尿, 体重減少を認めたこと，入院時の血 糖値が $526 \mathrm{mg} / \mathrm{dl}$ と高值であつたこと，ガス分析に てpHが7.16とアシドーシスがあり, 血中, 尿中ア セトン体が陽性であつたことより，本症例を糖尿 病性ヶトアシドーシスによる昏睡と考光，午前 10 時より少量インスリン持続注入療法, 輸液, 酸素 吸入を開始した（Fig 2). 少量インスリン持続注 入療法は輸液用の生理食塩水にactrapid insulin を混じ， 1 時間に 6 単位の割合で扢こなつた。輸 液は最初の 1 時間30分で $1500 \mathrm{ml}$ ，次の 1 時間で $500 \mathrm{ml}$ 行なつた。血清ナトリウムが入院時 169

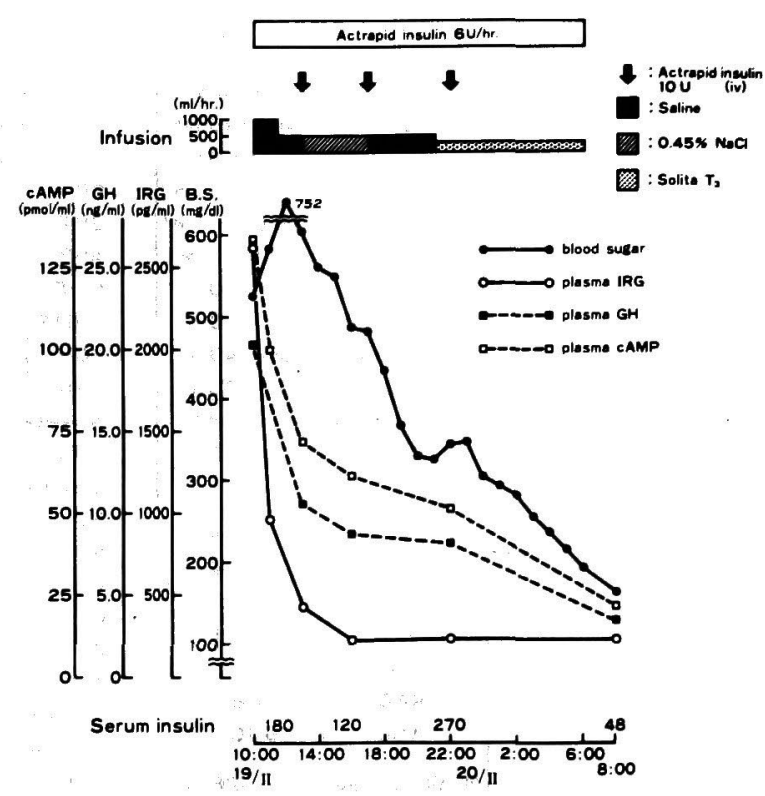

Fig 2. Changes in blood sugar. plasma IRG, GH and cAMP during continuous low-dose intravenous infusion of insulin.

$\mathrm{mEq} / l$, 午前 11 時 $172 \mathrm{mEq} / l$ であることが判明し た時点より $0.45 \%$ 食塩水を輸液した。入院時強い ショックのため血圧の測定ができない状態であつ たので, 生理食塩水 $500 \mathrm{ml}$ に酒石酸メタラミノー ルを $30 \mathrm{mg}$ 混じ持続点滴した. 治療開始後 1 時間 30 分経過した時点で血圧は $94 / 56 \mathrm{mmHg}$ ，脈拍は 120/分となつた。少量インスリン持続注入療法に もかかわらず，血糖値は午前 11 時 $582 \mathrm{mg} / \mathrm{dl}$, 午前 12 時 $752 \mathrm{mg} / \mathrm{dl}$ と上昇したため, 午後 0 時 30 分actrapid insulin 10単位を静注したところ，これ以後 血糖値は低下に転じた，午後 1 時頃には呼びか けに開眼するようになつた。午後 4 時頃には血 圧 $114 / 86 \mathrm{mmHg}$ となり, $\mathrm{pH} 7.25$, base excess $-6.5 \mathrm{mEq} / l, \mathrm{HCO}_{3}^{-} 20.8 \mathrm{mEq} / l$ と改善がみられ た。午後 5 時の血清ナトリウムが $166 \mathrm{mEq} / l$ とな つた時点より輸液は再び生理食塩水に変更した。 午後 8 時には血糖値が $330 \mathrm{mg} / \mathrm{dl}$ となつたので, 午 後 9 時よりソリタ $\mathrm{T}_{3}$ に輸液を変更した. 午後 12 時 頃には問いかけに返事をするようになつたが傾眠 状態であつた. 翌 2 月20日午前 6 時に血糖値は193 $\mathrm{mg} / \mathrm{dl}$ となり少量インスリン持続注入療法を中止 


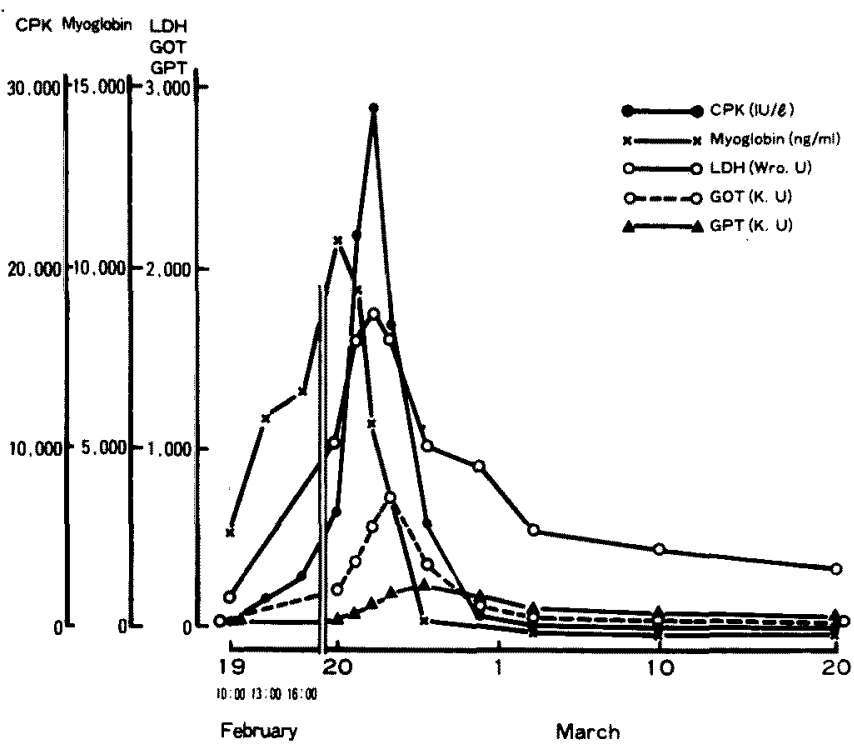

Fig 3. Changes in serum CPK, mytglobin, LDH, GOT and GPT

した。この時点までに投与されたactrapid insulin は, 持続注入にて120単位, 静注にて30単位であり, 輸液量は9lであつた。20日午前 8 時頃にはほぼ覚 醒した。少量インスリン持続注入療法を開始後血 采IRG, GH，cAMPはすみやかに低下し，装日に は正常化した. 20日午前の動脈血ガス分析ではpH 7.37 , base excess $-1.6 \mathrm{mEq} / l, \mathrm{HCO}_{3}^{-}$は23.0 $\mathrm{mEq} /$ ととすべて正常となつた.

2 月20日早朝より21日早朝にかけてンリタ $T_{3}$ を2000ml輸液し，20日タ食より果汁を与えた。20 日は午前 6 時actrapid insulin 12 単位，午前 12 時 actrapid insulin 10単位, 午後 6 時actrapid insulin 8 単位を皮下注射し，血糖值を $100 \sim 330 \mathrm{mg} / \mathrm{dl}$ に保つた。食事は21,22日は700カロリーとしたが， 23日以後は1200カロリーとした。

入院時（2 月19日）の血清GOT, GPT, LDH, CPKはTable 1に示すごとくすべて正常範囲にあ つたが，血清ミオグロビンのみはすでに高值であ つた. Fig 3に入院後の血清CPK, ミオグロビン, LDH, GOT, GPTの変動を示した．血清CPKは治 療開始後上昇しはじめ, 午後 4 時には $1518 \mathrm{IU} / l$ に 達した。2月20日の血清CPK，ミオグロビン， LDH, GOT, GPTはそれぞれ65721U/l, 11690ng/
Table 2. lsozyme of serum LDH and CPK

\begin{tabular}{|c|c|c|c|c|c|c|c|c|}
\hline \multirow{2}{*}{$\frac{\text { Date }}{\text { CPK (Iu/e) }}$} & \multicolumn{2}{|c|}{$\begin{array}{c}19 / \mathrm{II} \\
\text { AM } 10: 00 \text { PM } 4: 00\end{array}$} & \multirow{2}{*}{\begin{tabular}{|l|}
$20 /$ II \\
6572
\end{tabular}} & \multirow{2}{*}{$\frac{21 / \pi}{22000}$} & \multirow{2}{*}{$\frac{22 / 11}{29000}$} & \multirow{2}{*}{$\frac{23 / 11}{17000}$} & \multirow{2}{*}{$\frac{26 / 11}{2900}$} & \multirow{2}{*}{$\frac{3 / 11}{148}$} \\
\hline & 124 & 1518 & & & & & & \\
\hline BB (\%) & 0 & 0 & 0 & 0 & 0 & & 0 & \\
\hline ME & 1 & 1 & 2 & 2 & 2 & & 0 & \\
\hline$M M$ & 86 & 96 & 95 & 96 & 97 & & 97 & \\
\hline Alb. & 13 & 3 & 3 & 2 & 1 & & 3 & \\
\hline LDH (wro U) & 181 & & 1008 & 1606 & 1758 & 1693 & 902 & 584 \\
\hline $\mathrm{LDH}$; (क) & & & 19.4 & 13.5 & 14.3 & & 18.3 & \\
\hline $\mathrm{LDH}_{2}$ & & & 18.8 & 146 & 120 & & 36.0 & \\
\hline $\mathrm{LOH}_{3}$ & & & 25.4 & 15.0 & 11,4 & & 26.0 & \\
\hline $\mathrm{LDH}_{\Delta} \quad \%$ & & & 5.4 & 5.3 & 3.6 & & 6.2 & \\
\hline LDHs $\quad(\%)$ & & & 30.7 & 51.4 & 58.5 & & 12.6 & \\
\hline
\end{tabular}

ml, 1008Wro.U, 209K U, 46K U となつた. 血清 ミオグロビンは以後低下したが，血清CPK, LDH は22日最大値 $29000 \mathrm{IU} / l, 1758 \mathrm{Wro}$. Uk達し以後 减少した。血清GOTは23日に最大值 $747 \mathrm{~K} \mathrm{U}$, 血清 GPTは25日に最大値276K UK達し以後減少し た. Fig 1に入院時，2，3 日目の心電図を示すが， $\mathrm{ST}$ の上昇，異常Q波は認められなからた。む狭 心発作も認めなかつた。 上昇したCPK, LDHの由 来の検討をするためてイソザイムを検索した。 Table 2に示すごとく, CPKはMMが著増してお り，最大值29000IU/lを示した22日のアインザィ ムパターンはBB $0 \%, \mathrm{MB} 2 \%, \mathrm{MM} 97 \%$, Albumin 1\%であつた。 またLDHアイソザイムでは $\mathrm{LDH}_{5}$ が著増しており, 最大值 1758 Wro.Uを示し 


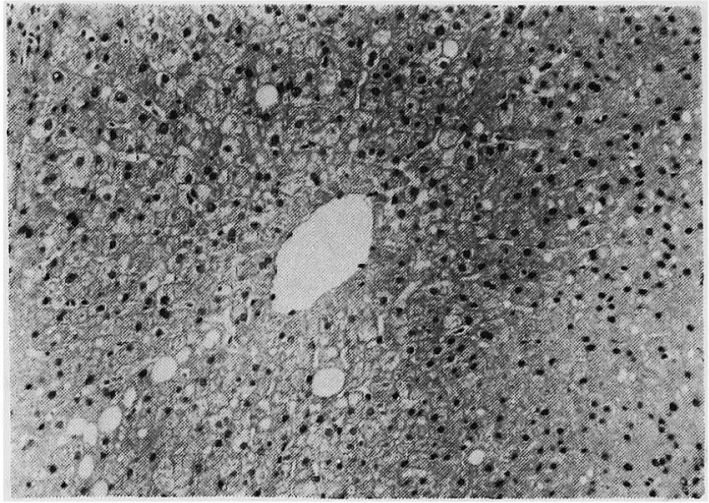

Fig 4. Photomicrograph of the liver(H-E stain).

た22日のアインザイムパターンは $\mathrm{LDH}_{1} \quad 14.3 \%$, $\mathrm{LDH}_{2} 12.0 \%, \mathrm{LDH}_{3} 11.4 \%, \mathrm{LDH}_{4} 3.6 \%, \mathrm{LDH}_{5}$ $58.5 \%$ あつた。これら血清CPK, LDHアイソザ イムの検索より, 心筇硬塞時に上昇する $\mathrm{MB}$, $\mathrm{LDH}_{1}$ の上昇がみられず, $\mathrm{CPK}, \mathrm{LDH}$ の上昇は心 筋由来である可能性は否定され，増加した酵素の 由来は骨格筋由来と考兄られた。な技 $\mathrm{CPK}$, myoglobin上昇時, 四肢および躯幹に疼痛, 腫脹は認め ず，筋炎その他の筋疾患を思わせる所見は認めら れなかつた。昏睡治療時に筋肉注射は行なつてい ない. 血清GOT, GPT, LDHの上昇に肝細胞障害
が関与している可能性を考えて 3 月 7 日肝生検を 実施したが, Fig 4 に示す如く, 光顕上肝細胞壊死 は認められなかつた。血清CPK，ミオグロビンは 3 月 10 日, 血清GOT, GPTは 3 月 10 日, 血清LDH は 3 月20日に正常值に復した。この間に行なつた 筋電図ではとくに異常を認めなかつた，筋生検は 実施しなかつた。

Fig 5 に入院中のインスリン投与量とFBSの変 動を示した。覚醒後インスリンは朝・昼食前に actrapid insulin, 夕食前にrapitard insulinを皮下 注射したが，2月25日より朝食前14単位，昼食前 18 単位, 夕食前 12 単位, 合計 44 単位を皮下注射し 経過を追つた。 3 月 5 日より低血糖症状が頻回に みられるようになつたため, インスリンの減量を はじめ，3 月 8 日より rapitard insulinの 2 分割投 与に変更した。 その後も順調にインスリン投与量 の減量が可能で, 3 月28日ょり lente insulin16単 位に变更した. 以後もFBSのコントロールは良好 であり，5月18日より食事療法のみとしたが， $\mathrm{FBS}$ は $100 \mathrm{mg} / \mathrm{dl}$ 前後に維持され, 5 月30日退院し た.なおFig. 6 に 3 月 4 日と 5 月 30 日の $100 \mathrm{~g} \mathrm{GTT}$ を示すが， 5 月 30 日の時点では耐糖能，および血 清Cーペプチド反応の改善が認められた。

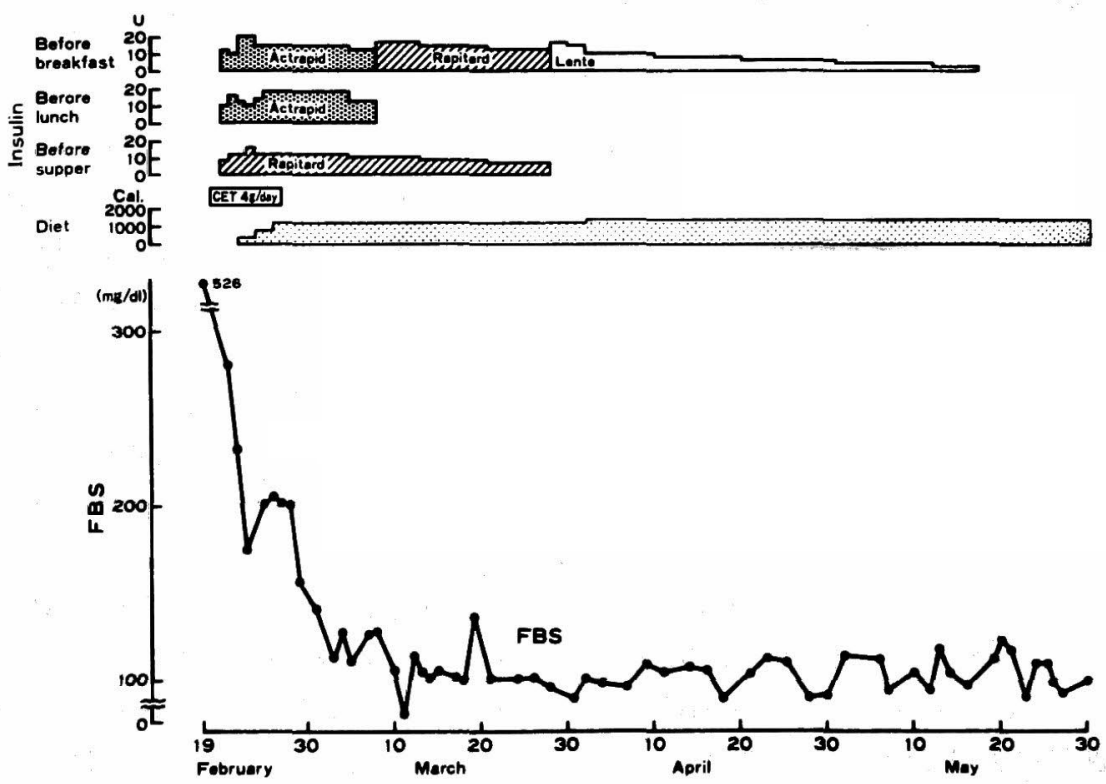

Fig 5. Clinical course. 


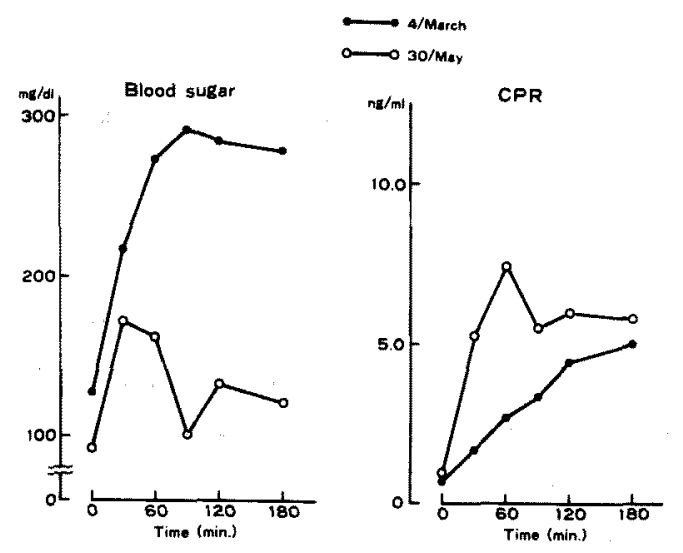

Fig 6. 100g OGTT.

\section{考 案}

糖尿病性ヶトアシドーシスに高CPK血症が認 められた時，まず第一に心筋硬塞の合併が考慮さ れるべきであろう。本症例において，Fig 1に示す ごとく, 入院時の心電図にはST低下が認められる ものの, ST上昇，異常Q波は認められず，心電図 上心筋硬塞を示唆する所見はなからた。さらに入 院時の翌日, 翌々日の心電図に㧍いても心筋硬塞 を疑わせる所見は認められなかつた。 CPKアイン ザイムの検索では，心筋由来の $\mathrm{MB}^{6}$ は 1 ～ $2 \%$ で，大部分は骨格筋由来のMMが95９7\%を占め ていた. したがつて本症例にみられた高CPK血症 は，骨格筋に由来するCPKが血中に増加したため に生じたことは明らかである。

糖尿病性ヶトアシドーシスに高CPK血症が合 併することは, Velez-Garciaらにより初めて報告 された2)。それによると，13例の糖尿病性ケトアシ ドーシスに拈いて, 治療前血清CPKは全例に打い て正常であつたが, 治療後11例に高CPK血症を認 め，その原因として急激な大量の輸液，大量のイ ンスリン投与により，筋肉細胞内への大量の水分 および電解質の移動がおこり，細胞膜に障害が括 こるためであると考えた2)。しかし高CPK血症を きたす心筋硬塞, 壊疽, 筋注などには触れておら ず，フインザイムについても検索されていなかつ た. Knightらは30症例36回の糖尿病性ケトアシ ドーシスに招いて, 心筋硬塞, 壊疽、筋注症例を
除くと， 2 症例に糖尿病性ヶトアシドーシスの治 療後原因不明の高CPK血症がみられたと報告し た3). Knightらの報告に括いてもCPKフイソザイ ムの検討がされて扔らず，高CPK血症の原因につ いては不明であつた，著者らが既に報告した症例 に招いても，高CPK血症は糖疗病性ヶトアシドー シスの治療後に認められ，CPKアインザイムの検 索ではMMが97〜98\%を占めていた5).しかし血 清ミオグロビンは測定されて招らず，高CPK血症 の成因については不明であつた。

本症例に怙いて，高CPK血症は治療前には諗め られなかつたが，治療開始後 6 時間で $1518 \mathrm{IU} / l$ と 上昇がみられ，過去の報告例と同様な血清CPKの 変動であつた，本症例に执いて測定された血清ミ オグロビンは，入院時 $2745 \mathrm{ng} / \mathrm{ml}$ と著明に上昇し ていた。このことは，入院時既に骨格筋の障害が 存在していたことを示唆して颃り，糖尿病性ヶト アシドーシスの際の高CPK血症の成因を考える 時興味深いなな゙なら，今をでの症例では血清 CPKの変動のみを観察し，糖疗病性ヶトアシドー シスの際の高CPK血症の成因を治療による水・電 解質，括よび代謝変動に求める考方が支配的であ つたからである。本症例の血清ミオグロビンの変 動は，治療以前の因子も成因として無視できない ことを示していると思われる，糖尿病性ヶトアシ ドーシスの治療前の因子のうち，骨格筋の細胞膜 透過性九進に重要な役割を果したものが何である かの決定はむずかしい。

まずWilkinsonらはヒト白血球およびラットリ ンパ球の研究により, 細胞膜透過性亢進に細胞内 adenosine triphosphate (ATP) 濃度の低下が重 要な役割を果していると提唱した7)。本症例に稼 いては入院時ショック状態であり，骨格筋はanoxiaにさらされていたことまた極度のインスリン 作用の不足のため糖利用の低下が存在していたこ となどが, ATP産生の極度の低下を䒩起していた ことは容易に想像されるところである.Zierlerk よつても実験的なanoxia，糖利用の低下により， 骨格筋の膜透過性が亢進することが報告されてい る8)。植田は脳卒中, 髄膜炎, てんかんなどの神経 
疾患時にみられる血清CPKの上昇が骨格筇由来 のCPKによる事実に着目し興味ある実験結果を 報告している9?. それによると，家鬼の視床下部の らち交感帯を電気刺激することにより血清CPK の上昇がみられたといら ち， $\boldsymbol{\alpha}$-stimulationにより血清CPKの上昇が認め られたといら ${ }^{10)}$. 糖尿病性ヶトフシドーシスにお いて血中カテコラミン，とくにノルアドレナリン が上昇していることが知られて拈り ${ }^{11) ， カ テ ュ ラ ~}$ ミンが骨格笳の細胞膜透過性亢進を若起させた可 能性む十分考えられる。さらに低カリウム血症が， 骨格筋障害に重要であるとの考点するる ${ }^{21}$. 一般 に糖尿病性ヶトアシドーシスでは血清カリウム值 が正常もしくは高值であつても，それは脱水によ るみかけ上のことであり，体全体では尿へのカリ ウム喪失のため, カリウムの欠乏状態にあること が知られている゙. Knochelらは, 細胞内カリウム 久乏は解糖を好気性解糖加嫌気性解糖へすす め, ATPの産生障害, 酸化的リン酸化障害を生ぜ しめ，骨格笳障害を拉こすと推論した ${ }^{13)}$. また筋肉 細胞内のカリウム欠乏は筋肉内細小動脈の抾張を 妨げ，笳肉の虚血を起こすとの考えすある ${ }^{22}$. 老粐 らは血糖 $710 \mathrm{mg} / \mathrm{dl}$, 血清カリウム $1.9 \mathrm{mEq} / \mathrm{l}$ であ つた糖疗病患者で, ミオグロビン尿症, 高CPK血 症を呈した 1 例を報告し，骨格筋障害に脱水，低 カリウム血症が関与していると推論している ${ }^{14)}$. 治療前の骨格筋障害に関与する因子について考察 してきたが，日常の臨床に执いてコントロール不 良の糖尿病患者に高CPK血症を経験することは なくまた最近非ケトン性高浸透王昏睡を呈した 糖病患者に高CPK血症がみられたと報告され ていることより ${ }^{15)}$ ，現時点では本症例にみられた 高CPK血症の機序として, 糖尿病性ヶトアシドー シスによる脱水，ショックが骨格筋のanoxiaを萩 起したとの推論が重要と思われる。

以上治療前の骨格筋障害に関与する因子につい て考察したが, Velez-Garciaの報告と同様に本症 例に和いてす血清ミオグロビン, CPK, LDH, GOTは治療後上昇した。この点について, VelezGarciaらは，急激な大量の輸液，大量のインスリ
ン投与により，筋肉細胞内人大量の水分および電 解質の移動がお゙こり，細胞膜が障害されるためで あると推論している，最近インスリン治療による 血清リンの低下か゚高CPK血症に関与していると の考えも示されて括り年16)，考虑すべき点である 5 .

入院後18日目に実施した肝生検では，肝細胞壊 死は否定されたが，上昇したGOT, GPT, LDHの 一部は重篤なショックのため一過性の肝障害によ る可能性も否定できない.LDHアインザイムの袷 索では，筋ジストロフィー，筋炎と異なり $\mathrm{LDH}_{5}$ が 上昇していた．これはショックによる筋肉からの LDHの遊出機序が，筋ジストロフィ一，筋炎と異 なるためかもしれない，また $\mathrm{LDH}_{5}$ の上昇は ショックによる一過性の肝障害による可能性も否 定できない。

以上重篤な糖尿病性ヶトアシドーシスにみられ た高CPK，高ミオグロビン血症の機序について考 察したが，いまた不明な点も多い。詳細な症例の 锶察，とくにショックを伴わないケトアシドーシ ス症例の観察を積上げていくことが重要である。

\section{結語}

糖尿病性ヶトアシドーシスに著明な高CPK, ミ オグロビン血症を伴つた症例を報告し，その機序 について考察を加えた。

碀辞 東京都立駒込病院 室 隆婎副院長, 朝日生命成 人病研究所内分泌代謝科, 暒沼宏部長の御助言に感謝いた し市す。

\section{文 献}

1) Beigelman PM : Severe diabetic ketoacidosis. Diabetes $20: 490,1971$.

2) Velez-Garcia F, et al: Cysteine-stimulated serum creatine phosphokinase. J Lab Clin Med $68: 636,1969$.

3) Knight AH, et al: Serum enzyme changes in diabetic ketoacidosis. Diabetes $23: 126,1974$.

4) Kreisberg RA : Diabetic ketoacidosis. Ann Int Med 88:681, 1978.

5）棚橋 忍，他：高CPK血症を合併した糖尿病性ヶ トフシドーシスの1例。糖尿病 $23: 165,1979$.

6) Wagner GS, et al: The importance of identification of the myocardial-specific isozymes of creatine phosphokinase (MB form) in the 
diagnosis of acute myocardial infarction. Circulation $47: 263,1973$.

7) Wilkinson $\mathrm{JH}$, et al: Effect of energy-rich compounds on release of intracellular enzymes from human leucocytes and rat lymphocytes. Clin Chem $20: 1331,1974$.

8) Zierler KL: Diffusion of aldolase from rat skeletal muscle. Amer J Physiol $190: 201,1957$.

9）植田啓嗣：神経・筋疾患の形態上譏能，生化学的 立場加ら。臨床病理 $22: 244,1974$.

10）植田啓嗣：ミオパチーと筋肉構造異常との慗が ク。日本臨床 $33: 1684,1975$.

11) Cristensen NJ, et al: Plasma norepinephrine and epinephrine in untreated diabetics, during and after insulin administration. Diabetes 23 : $1,1974$.
12) Knochel JP, et al: On the mechanism of rhabdomyolysis in potassium depletion. J Clin Invest $51: 1750,1972$.

13) Knochel JP, et al: Salt loading as a possible factor in the production of potassium depletion, rhabdomyolysis and heat injury. Lancet $1: 659$, 1967.

14）老粐宗忠，他：低カリウム血症を伴いmyoglobinuriaをたした糖尿病の 1 症例。糖疗病 20 ： 783, 1977.

15) Rumpf $\mathrm{KW}$, et al: Myoglobinurisches Nierenversagen bei hyperosmolarem diabetichem Koma. Dtsch Med Wschr 106: 708, 1981.

16) Fuller JJ, et al: Reversible changes of the muscle cell in experimental phosphorus deficiency. J Clin Invest $57: 1019,1976$. 